\title{
A magyar könyvvizsgálat történetének mérföldkövei a középkortól napjainkig
}

\section{Milestones in the Development of Hungarian Auditing from the Middle Ages to the Present}

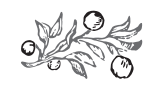

\section{Összefoglalás}

A könyvvizsgálat mint ellenôrzési tevékenység jelentôs szerepet tölt be a piacgazdaságban, kialakulását a piac érdekei tették szükségessé. Az audit mint ellenôrzés valamely rendszer, szervezet céljainak és feladatainak hatékony megvalósítása érdekében végzett tevékenység, amely tényeket feltárva, azokat a meghatározott követelményekhez viszonyítva, javaslatok megfogalmazásával támogatja a vezetést. Az elmúlt években a könyvvizsgálói tevékenység elótérbe kerülése több okra vezethetô vissza. A megváltozott jogszabályi környezetben felmerülhet a kérdés, hogy a túlszabályozott piacon hogyan valósulhat meg a hatékony könyvvizsgálat, másrészt az elmúlt évek auditbotrányai okán is elôtérbe került a könyvvizsgálat fontossága. A könyvvizsgálat jelenlegi helyzete és szabályozása egy állandóan fejlôdô folyamat eredménye. Tanulmányunkban a könyvvizsgálati tevékenység történetét tekintjük át, annak kialakulásától napjainkig. A szisztematikus szakirodalom-kutatás során kérdésként kezeljük, hogy a könyvvizsgálat kialakulása folyamán melyek voltak a jelenlegi szabályozásban szerepet játszó kulcstényezók. Arra keressük a választ, hogy mennyire van hatással a könyvvizsgálat története, kialakulása annak jelenlegi helyzetére, minőségére, szabályozására.

LUKÁcs LÁszLó IsTVÁN vezetô kormánytanácsos, Innovációs és Technológiai Minisztérium Költségvetési Fóosztály, segédkutató, Budapesti Gazdasági Egyetem Pénzügyi és Számviteli Kar (lukacs.laszlo87@gmail.com), Töröк Martina Zsófia egyetemi tanársegéd, Budapesti Gazdasági Egyetem Pénzügyi és Számviteli Kar (torok.martinazsofia@uni-bge.hu). 
Journal of Economic Literature (JEL) kódok: M42, N43, N44

Kulcsszavak: könyvvizsgálat, számvitel, ellenôrzés, minôségmérés, történelem

\begin{abstract}
Summary
Audit plays a significant role in the economy, and its emergence was driven by market interests. Audit is an activity that is carried out to efficiently achieve the goals and tasks of an organization. Audit discloses facts and supports the management by finding and adjusting facts to the prevailing conditions and by making recommendations. Audit activity has come to the fore in recent years, due to several reasons: the changed legal environment may raise the question of efficiency in auditing in an overregulated market, on the one hand, and the audit scandals seen in recent years have also highlighted the importance of auditing, on the other. In this study, the history of audit activity is given from its inception to the present. In this study the impacts of the history of auditing on its current situation, its quality and its regulation are analysed.
\end{abstract}

Journal of Economic Literature (JEL) codes: M42, N43, N44

Keywords: audit, accounting, control, quality measurement, history

\title{
BEVEZETÉS
}

Az elsô társadalmak megjelenése óta, amikor kialakult az uralkodó réteg, fontos szerep jutott az adók és a vagyon számbavételének. A számbavétel mellett megjelent az igény a nyilvántartások ellenôrzésére, bizonyítandó, hogy azok valós adatokat tartalmaznak. Az évszázadok során a könyvvitel folyamatosan fejlődött, és ez magával vonta a könyvvezetés ellenőrzésének fejlődését is, kialakult a könyvvizsgálat. Tanulmányunkban elsôsorban a magyar könyvvizsgálat történetével foglalkozunk, annak kialakulásával és jogi szabályozásának fontosabb mérföldköveivel, ahol szükséges, nemzetközi kitekintéssel. A folyamatban lévô kutatásunkkal az a célunk, hogy megismerjük a hazai könyvvizsgálat történetét, a szabályozás, oktatás és az alkalmazott módszertan fejlődését. Kitûzött céljaink kijelölik a kutatás részterületeit, szakaszait. Jelenlegi tanulmányunk kiemelten a szabályozás témakörével foglalkozik. Úgy gondoljuk, hogy a könyvvizsgálat múltját szükséges megismerni ahhoz, hogy a szakma tovább fejlődhessen.

\section{ANYAg ÉS MÓDSZER}

A könyvvizsgálat történeti áttekintéséhez és ezzel összefüggésben a szabályozás hátterének bemutatásához nélkülözhetetlen vizsgálni a könyvvizsgálat fejlődésének főbb szakaszait, hiszen a jelenlegi szabályozásra, könyvvizsgálattal kapcsolatos kérdésekre is hatással vannak. Magyarországon még nem született olyan kutatás, amely a könyv- 
vizsgálat történetével, illetve arra ható fốbb összefüggések vizsgálatával foglalkozott volna, szakmai és tudományos oldalról egyaránt. A kutatásunk elsô lépése egy mély szakirodalom-kutatás volt, mely során a témában megjelent mérvadó tanulmányokat kutattunk fel, majd ezeket megfeleló módszerekkel szintetizáltuk. A témakör szempontjából lényeges folyóiratokat, cikkeket tekintettünk át a számvitel, könyvvizsgálat és elemzés, ellenôrzés témákban, feldolgoztuk a korabeli jogszabályokat, szakkönyveket, és jogdinamikai vizsgálatokat is végeztünk. A téma fontosságát mutatja, hogy az elmúlt években megtöbbszöröződött a tanulmányok száma. A témában megjelent cikkeket nemcsak a történeti áttekintés szempontjából vizsgáltuk, hanem aszerint is, hogy a hazai fejlódésre milyen hatással lehetnek.

\section{A KÖNYVVIZSGÁlATI TEVÉKENYSÉG CÉLJA}

A könyvvizsgálói tevékenység mint ellenôrzés jelentôs szerepet tölt be a piacgazdaságban, kialakulását a piac érdekei tették szükségessé. Az ellenốrzés valamely rendszer, szervezet céljainak és feladatainak hatékony megvalósítása érdekében végzett tevékenység, amely tényeket tár fel, és azokat a meghatározott követelményekhez viszonyítva, javaslatok megfogalmazásával támogatja a vezetést. Az ellenôrzés célját az általa képviselt érdekek határozzák meg, ennek alapján tulajdonosi és hatósági érdeket különböztethetünk meg. Az ellenőrzés egyfajta megfigyelô, összehasonlító és értékelô tevékenység, amely három, egymással összefüggố részbôl áll: megállapítja a tényeket, azokat viszonyítja a megfogalmazott elvárásokhoz, szabályokhoz, végül értékeli a viszonyítás eredményeit. Az ellenôrzés fố feladata a vizsgált jelenség, tevékenység, folyamat vagy szervezet eredményességének elósegítése. Az ellenôrzés gyakorisága szerint lehet: folyamatos ellenôrzés (pl. bizonylatok ellenôrzése); ismétlódó, idôszakos ellenôrzés (pl. hatósági ellenôrzés, éves beszámoló könyvvizsgálata); esetenkénti ellenôrzés (pl. leltárhiány vizsgálata).

A vállalkozások ellenôrzési rendszerében a könyvvizsgálati tevékenységnek van jelentốs szerepe, hiszen a cél annak megállapítása, hogy a szervezet számviteli beszámolója a jogszabályi elôírások szerint készült-e, illetve valós képet ad-e a vállalkozás vagyoni, pénzügyi és jövedelmi helyzetéról (Kresalek, 2014).

\section{A KÖNYVVIZSGÁLAT TÖRTÉNETI ÁTTEKINTÉSE}

A könyvvizsgálat jelenlegi helyzete és szabályozása egy állandóan fejlődő folyamat eredménye. Az audit kialakulása, történelmi fejlődése, illetve annak kezdeti szakasza kevéssé dokumentált, viszont az ókori Egyiptom, Kína és Görögország területén talált feljegyzések arra engednek következtetni, hogy idôszámításunk előtt 350-ben már múködött a könyvvizsgálat, az akkori kornak megfelelô formában. ${ }^{1}$ Arab kulturális területen a 7-8. században, a Korán iránymutatásai alapján, amely elôírja a gazdasági ügyletek írásba foglalását is, már kialakult egy könyvviteli rendszer. Ebben a rendszerben megkövetelték a minden részletre kiterjedô könyvvezetést, és a könyvvizsgálat is kötelezố volt (Zaid, 2004). 
A jelenlegi könyvvizsgálati tevékenységgel leginkább összefüggő, máig fennmaradt feljegyzés 1314-ból, Angliából származik, amely az államkincstár ellenôrét (Auditor of the Exchequer) említi. Ebben az időben a kincstár ellenőrzését speciálisan erre a feladatra kinevezett könyvvizsgálók, illetve az államtitkár könyvvizsgálója végezhette. I. Erzsébet királynố 1559-ben alapította meg a költségvetés ellenôreinek szervezetét (auditors of imprest), amely az angol korona tisztviselôinek számláit ellenôrizte, illetve azt, hogy a haditengerészet tisztségviselőknek kiadott jelentôs pénzösszegeket ténylegesen a meghatározott célokra használják fel. A rendszer múködóképesnek bizonyult, habár a könyvvizsgálók nem ellenórizték a hadsereg és a haditengerészet igazgatásával foglalkozó szervezeti egységek tényleges kiadásait. Nem volt semmi mechanizmus annak biztosítására sem, hogy a számlákat bemutassák, és haladéktalanul átadják. A szervezet 1785-ig múködött. Késôbb, pénzügyminiszterként William Ewart Gladstone nagymértékú reformokat kezdeményezett az államháztartás és a parlamenti elszámoltathatóság érdekében. Az 1866-os Exchequer and Audit Departments Act (Vagyonkezeló és ellenôrzési osztályok törvénye) elôször kötelezte az összes szervezeti egységet éves beszámolók készítésére. A törvény megállapította továbbá a közigazgatás és a könyvvizsgáló osztály pozícióját a közszolgálaton belüli támogató személyzet biztosításához. A két fố feladatuk volt: engedélyezni az államháztartás kiadását a Bank of Englandból, ezen túlmenôen ellenôriznie kellett valamennyi kormányzati szerv számláit, melyek alapján jelentést tett a parlamentnek (Sainty, 1983).

Angliában a 19. század elején a gazdasági élet szereplói felismerték, hogy a társasági szervezetek ellenôrzése nem megbízható, így független, autonóm ellenôrzés bevezetését szorgalmazták. Ennek eredményeként a törvényhozás elrendelte az ellenôrzést először egyfajta választható kötelezettségként, késôbb egyre szélesebb körben kötelezốen előírta azt. Az elsố egyesület, amely revizori tevékenységet látott el, 1853ban Skóciában alakult meg, majd 1870-ben létrejött a világ legtekintélyesebb számviteli egyesülete (Institute of Chartered Accountants in England and Wales). 1885-ben további revizori egyesület alakult The Society of Accountants and Auditors néven, mely szervezet tagjainak szigorú szakvizsgát kellett tenniük, és erkölcsi megbízhatóságot követeltek tôlük (Borbás, 2007). Ezt követôen, az angol mintát követve, Európa több államában létrejött az állami felügyeleti ellenôrzés helyett a független ellenôrzés. Az 1870-ben elfogadott német szabályozás, az angoltól eltéróen, nemcsak a számvitel helyességére, de az ügyvezetés gazdasági célszerúségére is felügyelt. Szintén Németországban, a nagy gazdasági világválság hatására, 1931-ben rendelet mondta ki a könyvvizsgálat intézményének bevezetését (Securs, 2014).

Franciaország az angol szabályozást mintául véve, az 1867. évi törvényben meghatározta a könyvvizsgálatra vonatkozó legalapvetôbb szabályokat. Három évvel késôbb Németországban az állami felügyeleti ellenôrzés helyébe a független ellenôrzés, vagyis a könyvvizsgálat lépett (Borbás, 2007). A 19. század végén és a 20. század elején világszerte születtek számviteli jogszabályok, melyekben a könyvezetés mellett a könyvvizsgálatot is szabályozták, és sorra alakultak a nemzeti szakmai szervezetek. Európán kívül jelentôs szakmai fejlődés történt e téren az Oszmán Birodalomban, Japánban, Kínában (Lukács, 2012). 
Lukács László István - Török Martina Zsófia: A magyar könyvvizsgálat történetének...

A SZÁMVITEL ÉS KÖNYVVIZSGÁlAT MAGYARORSZÁGI TÖRTÉNETE

A számviteli szabályozás és könyvvizsgálat elözményei Magyarországon

Magyarországon a könyvvezetés és a pénzügyi ellenôrzés kezdetei a királyi bevételek beszedéséhez köthetôk. A 15. században Hunyadi Mátyás uralkodása idején a kincstartó vezetésével pénzügyi fơhivatal jött létre, de a számadások ellenôrzésére még nem született gyakorlat (Kenyeres, 2012a). A Habsburgok magyarországi uralkodása kezdetén, I. Ferdinánd (1526-1564) és I. Miksa (1564-1576) idején a birodalomban az akkori korhoz viszonyítva modernnek számító pénzügy-igazgatási reformok jöttek létre. Lényeges változások születtek a kamarai rendszerben, megalakultak a könyvvizsgálói-ellenôri kamarai szervek. Egyre több képzett, sốt egyetemet is végzett szakember jelent meg a pénzügyigazgatásban. A Magyar Kamara a Császári Kamara alárendelt szerveként múködött (Kenyeres, 2012b).

A kereskedelmi könyvek vezetésére vonatkozó elsô jogszabály Magyarországon III. Károly király 1723-ban kiadott kereskedelmi dekrétumának az LIII. cikkében található. A jogszabály szerint minden kereskedônek kötelessége volt rendszeresen és szabályosan vezetni a könyveit, és abban a hitelezéseirôl pontos nyilvántartást készíteni (Kardos, 2011; Sztanó, 2015). A kereskedelmi dekrétum továbbá kitért arra is, hogy a számlákat és szerződéseket hiteles személynek is alá kell írnia, biztosítva annak valóságtartalmát, ezzel vált hitelessé a dokumentum (Kereskedelmi dekrétum; Borbás, 2007). Ha az adós nem fizetett, három évig volt lehetôség peres úton behajtani a követelést. A per megindításához szükség volt az eredeti dokumentumok és fôkönyvek bemutatására, tehát ajánlott volt legalább három évig megórizni a kereskedelmi könyveket (Kereskedelmi dekrétum).

Jogi szabályozás szempontjából a magyar számvitel történelmében még meghatározó szerep jut az 1840. évi törvényeknek. A XV. törvénycikk a váltótörvénykönyvről és a XVI. törvénycikk a kereskedôkrôl (Kereskedői törvénycikk) részei tartalmaznak utasításokat az üzleti könyvek vezetésére, az elszámolási szabályok betartására és a feljegyzések bizonyító erejére vonatkozólag. A törvény elôírta a napló és a fôkönyv vezetésének kötelezettségét (Sztanó, 2015). Mindkét jogszabály elôírta a kereskedelmi könyvek hitelesítését és hatóságoknál való bejegyzését, a könyvelóknek pedig esküt kellett tenniük, hogy az általuk vezetett könyvek valós adatokat tartalmaznak. A kereskedelmi könyveket alapesetben másfél évig kellett megórizni, addig volt mód a hitelességét megtámadni, és kötelezô volt mérleget készíteni (Kereskedói törvénycikk). A pénzintézetek esetében már az 1860-as években felmerült a kötelezô könyvvizsgálat gondolata a gyakori csôdhelyzetek megelőzése érdekében, ezek a törekvések azonban nem valósultak meg (Kuntner, 1939²).

A magyarországi számvitel történetének következô jelentôs állomása az 1875. évi XXXVII. kereskedelmi törvény (Kt.), mely elsôként írta eló Magyarországon a könyviteli kötelezettséget. A kereskedelmi törvénykönyv megalkotásánál, melyet a kereskedelem dinamikus fejlődése követelt meg, külföldi kereskedelmi törvényeket vettek alapul, többek között a német kereskedelmi törvényt, és ezeket a szabályozásokat ültették át a 
magyar gazdasági viszonyokra. Továbbá a törvény jelentôsége abban áll, hogy miután még nem létezett polgári törvénykönyv, a bíróságok a kereskedelmi jogszabályokat alkalmazták a magánjogban is (Sztanó, 2015). A kereskedelmi törvény szabályozta a gazdasági társaságokat: a közkereseti társaságot, a betéti társaságot és a részvénytársaságot, emellett a felügyelőbizottsággal és a felszámolással kapcsolatos kérdésköröket is.

\section{A könyvvizsgálat Magyarországon 1950-ig}

A Magyar Könyvviteli Folyóirat legelsố száma, az elsô számviteli és kereskedelmi témájú tudományos szaklap Magyarországon 1908 januárjában jelent meg. A számvitel mellett külön könyvszakértői rovattal is rendelkezett, amely rendszeres tájékoztatást nyújtott a fejlett országok könyvvizsgálati gyakorlatáról (Borbás, 2007). 1911. március 7-én megalakult a Magyar Revizori Szövetség. Az 1916. évi XIV. törvénycikkel létrehozták a Pénzintézeti Központot, melyet az 1920. évi XXXXVII. törvénycikkel újraszabályoztak (Kuntner, 1939; Borbás, 2007). A Pénzintézeti Központ a kisebb pénzintézetek ellenôrzését tette kötelezôvé (Borbás, 2007), az ellenôrzési utasításában a belsô ügykezelés, üzletvezetés, fơkönyv, mérleg, eredménykimutatás és a leltár felülvizsgálatát írta elô (Vál-Jaszenovics, 1926). A Magyar Revizori Szövetség 1919-ben átalakult Magyar Revizorok Szövetségévé, amely a Tanácsköztársaság bukásával megszúnt. 1925-ben a Kereskedelmi és Iparkamara a könyvszakértőket kinevezte hites kamarai revizorokká, 1926. június 18-án megalakult a Kamarai Hites Revizorok Egyesülete (Kuntner, 1939; Borbás, 2007). A kereseti adószabályok hivatalos összeállításáról szóló 1927. évi 300. P.M. számú rendelet és a társulati adószabályok hivatalos összeállításáról szóló 1927. évi 400. P.M. rendelet alapján, ha a nyereség-veszteség számla (eredménykimutatás), a mérleg és leltár alapján megállapított vagyon- és jövedelemérték a Magyar Királyi Adóhivatal véleménye szerint nem volt megfelelő, a gazdálkodó esetében elrendelhette a könyvvizsgálatot. A könyvvizsgálat során a könyvvizsgálónak a könyvvezetés szabályszerúségének ellenőrzése mellett a helyes adóértéket is meg kellett állapítania. Ha az adóhivatal elrendelte a könyvvizsgálatot, a végzés ellen fellebbezésnek helye nem volt (Erdély, 1930).

Lényeges szabályozás a hazai számvitel szempontjából az 1930. évi V. törvény a korlátolt felelôsségú társaságokról (Kft. törvény), amely a Kereskedelmi törvény mellett további elôírásokat tartalmazott a könyvitelre vonatkozóan. Ez a törvény rendelkezett a hites könyvvizsgálói tevékenységrôl, a kft.-nek lehetôséget biztosított arra, hogy könyvvizsgálót válasszon. A hites könyvvizsgáló a társaság könyveit bármikor megtekinthette, az iratokat, pénztárt, az értékpapír-, árukészlet-állományát és berendezéseit bármikor megvizsgálhatta, a vállalat vezetésétôl bármikor információkat kérhetett. A könyvvizsgálónak kötelessége volt a könyveket és a beszámolókat megvizsgálni, és errôl írásos jelentést kellett készítenie a taggyúlés részére. A taggyúléseken személyesen részt vehetett, sôt összehívási joggal is rendelkezett. A könyvvizsgáló ugyanakkora felelôsséggel rendelkezett, mint a felügyelőbizottság: a jogszabály által előírt esetekben kártérítési kötelezettségük volt. Ilyen esetnek számított az, ha a jelentésükben valótlan adatokat közöltek, vagy elmulasztották a szakértők alkalmazását olyan ügyekben, melyek megkövetelték volna. A jogszabály továbbá utalást tesz más jogszabályokra a könyvvizsgálói képesítés megszer- 
zésére vonatkozóan. Az oktatást akkortájt az igazságügyi miniszter, a kereskedelemügyi miniszter és a pénzügyminiszter rendeletei szabályozták (Kft. törvény). A kormány a könyvvizsgálatra vonatkozó részletes előírásokat a 45.000/1931. I. M. számú Kft. törvény végrehajtásáról szóló rendeletében szabályozta (Kuntner-Szél, 1932; Kuntner, 1939). A Kft. törvény hiányosságai közé sorolható, hogy a könyvvizsgálatot nem tette kötelezôvé, csak döntési lehetôséget adott a felügyelóbizottság mellett vagy helyett történô igénybevételére, ennek következtében a vállalkozások a költséghatékonyság érdekében nem vették igénybe könyvvizsgálók szolgáltatásait. Emellett a Kft. törvény nem terjedt ki a részvénytársaságokra, így ennél a társasági formánál nem volt előírás a könyvvizsgálat, mely egyértelmúen a részvénytársaságok érdekérvényesító képességének eredménye (Borbás, 2007). A 14.000/1932. I. M. számú rendelet a Kft. törvény végrehajtási rendeletét módosította, a könyvvizsgálatra vonatkozóan átfogó változásokat tartalmazott. A rendelet késôbbi módosításai a könyvvizsgálók képesítésére vonatkoztak (Rajty, 1941).

1932-ben a magyar könyvvizsgálók szakmai szervezetbe tömörültek, és megalakult a Magyar Hites Könyvvizsgálók Egyesülete (Borbás, 2007). A Kuntner Róbert és Szél Jenô által szerkesztett Magyar Könyvviteli Folyóirat egy teljes lapszámot szentelt a könyvvizsgálatnak, a szabályozás és az oklevélmegszerzés feltételei ismertetésének (Kuntner-Szél, 1932). A zsidók közéleti és gazdasági térfoglalásának korlátozásáról szóló 1939. évi IV. törvénycikk a könyvvizsgálókra nézve is tartalmazott előírásokat, korlátozásokat. A törvénycikk előírta, hogy csupán a könyvvizsgálók hat százaléka lehet zsidó származású (Rajty, 1941). Steiner Vilmos egy 1941-ben tartott előadásában mutatott rá arra, hogy a magyar vállalatok bizalmatlanok a könyvvizsgálattal szemben, mert minden évben más végezte a feladatot, ami az ellenôrzés hatékonyságát is csökkentette, mivel a könyvvizsgáló nem támaszkodhatott az elôzó években a vállalatról megszerzett ismereteire. Német mintát követve szorgalmazták, hogy a könyvvizsgálat bizalmi szolgáltatás legyen, könyvvizsgáló társaságok jöjjenek létre, és az ellenôrzést ugyanaz a személy végezze több éven át. Ezzel együtt a kötelezó könyvvizsgálatot szerették volna a részvénytársaságokra is kiterjeszteni, a németországi gyakorlathoz hasonlóan (Steiner, 1941). 1941ben Magyarországon már 579 bejegyzett hites könyvvizsgáló dolgozott (Rajty, 1941).

A második világháborút követôen, a pengó nagymértékú inflációja következtében, 1946-ban bevezették a forintot, ezzel párhuzamosan az 1.790/1947. M.E. számú rendelet meghatározta a forintmérleg készítését. A nyitómérleget az új fizetôeszközben 1947. január 1. dátummal kellett elkészíteni, és hites könyvvizsgálóval hitelesíttetni, záradékoltatni (Zwierina, 1949; Borbás, 2007). A 230/1950. (IX. 7.) MT számú rendelet kimondta, hogy a hites könyvvizsgálat intézménye megszúnik, a Hites Könyvvizsgálók Országos Szövetségének közgyúlésén, 1950. szeptember 15-én pedig kimondták a szövetség feloszlását (Borbás, 2007).

\section{A magyar könyvvizsgálat 1950-tôl napjainkig}

Miután 1950-ben a hites könyvvizsgálat intézménye megszúnt, a könyvvizsgálók a „hites” helyett az „okleveles” jelzőt kapták. Az okleveleket a Pénzügyminisztérium Számviteli Képesítô Bizottsága adta ki. A könyvvizsgálók igazságügyi könyvszakértôként te- 
vékenykedtek, állami vállalatok belsô ellenôrzésében vettek részt, vagy az adóhivatal ellenôrzéseit folytatták le. A könyvvizsgálók képzése ettôl függetlenül folyamatos volt. 1956-ban a Pénzügyminisztériumnál kezdeményezés indult az Okleveles Könyvvizsgálók és Mérlegképes Könyvelők Szövetségének létrehozására, ám ez a történelmi helyzet miatt végül nem valósult meg. 1965-ben megalakult az Igazságügyi Könyvszakértôi Bizottság, 1967-ben a Magyar Könyvszakértôk Társasága. Az 1980-as évek második felében hatalmas átalakuláson ment keresztül a magyar gazdasági rendszer, amely következtében 1987. október 1-jén megalakult a Magyar Könyvvizsgálók Egyesülete (Borbás, 2007; Lukács, 2014).

A könyvvizsgálat intézményét a gazdasági társaságokról szóló 1988. évi VI. törvény élesztette újjá, mely kötelezóen előírta a könyvvizsgálatot. A számvitelrôl szóló 1991. évi XVIII. törvény konkrét előírásokat határozott meg a könyvvizsgálói jelentésről, meghatározta a könyvvizsgálatra kötelezettek körét és a záradék normaszövegét. A számviteli törvény felhatalmazása alapján a 46/1992. (III. 13.) Korm. rendelet részletesen szabályozta a könyvvizsgálat rendjét. Az egyesület 1991-ben Magyar Könyvvizsgáló Kamarára (MKVK) változtatta a nevét, és 1992-ben a Könyvvizsgálók Világszövetsége (IFAC) a tagjai sorába vette. Ebben az évben a kamara területi szervezeteinek kialakítása is megkezdődött. A könyvvizsgálat rendjét szabályozó kormányrendeletet a Magyar Könyvvizsgálói Kamaráról és a könyvvizsgálói tevékenységrôl szóló 1997. évi LV. törvény váltotta fel (Borbás, 2007; Lukács, 2014). A Kamara elnöksége 1997-ben döntött a IFAC sztenderdjein alapuló nemzeti könyvvizsgálati sztenderdek kialakításáról, 1998-ban pedig döntés született azok oktatásáról és fokozatos bevezetéséról. A Kamara 2002-ben teljes jogú tagjává vált az Európai Könyvvizsgálók Szervezetének (FEE). Az európai uniós jogharmonizáció következtében újra kellett kodifikálni a könyvvizsgálatra vonatkozó törvényt, ekkor jött létre a Magyar Könyvvizsgálói Kamaráról, a könyvvizsgálói tevékenységrôl, valamint a könyvvizsgálói közfelügyeletrôl szóló 2007. évi LXXV. törvény (Borbás, 2007).

\section{A könyvvizsgálat napjainkban}

Magyarországon az elmúlt években többször változott a könyvvizsgálat szabályozása, így az is, hogy mely szervezetek számára kötelezô e tevékenység. Korábban nem volt kötelezô könyvvizsgálót alkalmazni abban az esetben, ha a vállalkozás éves nettó árbevétele nem haladta meg a 200 millió forintot, a foglalkoztatottak száma pedig az 50 fốt. A jelenleg hatályos számviteli törvény szövege viszont megszabja, hogy azoknál a vállalkozóknál nem kötelezô a könyvvizsgálat, ahol az alábbi két feltétel együttesen teljesül:

- „az üzleti évet megelőző két üzleti év átlagában a vállalkozó éves vagy éves szintre átszámított nettó árbevétele nem haladta meg a 300 millió forintot, és

- az üzleti évet megelôzó két üzleti év átlagában a vállalkozó által átlagosan foglalkoztatottak száma nem haladta meg az 50 fơt.” [2000. évi C. törvény, 155. § (3) bekezdés.]

A törvény meghatározza azoknak a szervezeteknek a körét, melyek esetében a fenti két feltétel teljesülése esetén is kötelezô a könyvvizsgálat. Ilyenek a takarékszövetkeze- 
Lukács László István - Török Martina Zsófia: A magyar könyvvizsgálat történetének...

tek, a konszolidálásba bevont vállalkozások, a külföldi székhelyú vállalkozás magyarországi fióktelepei, a közérdeklődésre számot tartó gazdálkodók és a befektetési vállalkozások.

Költségvetési szervek esetén az egészségügyi ellátórendszer fejlesztésérôl szóló 2006. évi CXXXII. törvény 12. §-a alapján kötelezô a könyvvizsgálat azon egészségügyi szolgáltató szerveknél, ahol az Egészségbiztosítási Alapból finanszírozott ellátások összege eléri a 300 millió forintot, emellett az állami vagyonnal való gazdálkodásról szóló 254/2007. (X. 4.) Korm. rendelet 17. §-a szerint annál az állami vagyont kezelô szervezetnél kötelező a könyvvizsgálat, amely legalább 100 millió forint bruttó nyilvántartási értékú állami vagyont kezel. 2013. január 1-jén megszúnt az önkormányzatok esetében a kötelezó könyvvizsgálat (Printz, 2013).

A könyvvizsgálati értékhatár felemelése mellett más jogszabályi változások is megjelentek, amelyek jelentős változásokat hoztak a könyvvizsgálat területén. A könyvvizsgálói jelentéssel, a függetlenséggel, a szakmai szkepticizmussal kapcsolatban is születtek új szabályok, valamint a közfelügyeleti hatóság szerepköre is bôvült az elmúlt néhány évben. Ezeken túl változott a minőség-ellenőrzés és a könyvvizsgáló által nyújtható szakmai szolgáltatások szabályozása, bővült az auditbizottság feladatköre, valamint a kötelezô rotáció szabályai is megjelentek.

Az elmúlt években a könyvvizsgálati reform elôtérbe került mind hazai, mind nemzetközi szinten. Megfogalmazódott az igény, miszerint a számviteli beszámolóról készült könyvvizsgálói jelentés felhasználóinak elvárásai és a könyvvizsgáló által nyújtott szolgáltatás összhangban legyenek, illetve szükségessé vált a könyvvizsgálat hatókörének tisztázása is. Bôvült a független könyvvizsgálói jelentés tartalma, amely alapján a könyvvizsgálónak nyilatkoznia kell az olyan eseményekkel vagy feltételekkel kapcsolatos lényeges bizonytalanságokról, amelyek jelentôs kétséget támasztanak a gazdálkodónak a vállalkozás folytatására vonatkozó képességével kapcsolatosan. A könyvvizsgálók függetlenségére és objektivitására vonatkozó szabályokat kiterjesztették a könyvvizsgálat eredményét közvetlenül vagy közvetve befolyásolni képes más személyekre is. Új szabályok jelentek meg a vizsgált üzleti év során felvásárlásban vagy egyesülésben érintett gazdálkodóval szembeni függetlenség ismételt értékelésére. A megbízás megszúnését követô foglalkoztatási tilalmakra vonatkozóan rögzítették, hogy a könyvvizsgáló a vizsgált gazdálkodónál a megbízás megszúnését követô legalább egy éven át (közérdeklődésre számot tartók könyvvizsgálata esetén legalább két éven át) nem tölthet be vezetô tisztséget, nem lehet az auditbizottságának, felügyelootestületének tagja, irányító testületének ügyvezetố tagja. A közfelügyeleti hatóság az európai uniós 2014/56/EU irányelv szerinti végsố felelôsséggel bíró illetékes hatóság. Ez alapján az érdekképviseleti szervnek minôsülő Magyar Könyvvizsgálói Kamara nem járhat el az irányelv szerinti illetékes hatóságként, a közfelügyeleti hatóság azonban bizonyos közfelügyeleti feladatok ellátását a kamarára delegálja azzal, hogy a feladatokért végsó felelősséggel a közfelügyeleti hatóság bír. A továbbiakban is a kamara látja el a kamarai tag könyvvizsgálók és könyvvizsgáló cégek nyilvántartásba vételét, a harmadik országbeli könyvvizsgálók jegyzékbe vételét, a fegyelmi eljárások lefolytatását, ugyanakkor a közfelügyeleti hatóság jogosult a könyvvizsgálói tevékenység végzéséhez szükséges szakmai és gyakorlati 
tudás igazolására. Míg a közfelügyeleti hatóság folytatja le a közérdeklôdésre számot tartó gazdálkodók könyvvizsgálóinak minôség-ellenôrzését legalább háromévente, addig továbbra is a kamara végzi a nem közérdeklődésú gazdálkodók könyvvizsgálóinak minôségbiztosítását, hatévente legalább egyszer. A kamarai minôség-ellenőrzési eljárás során viszont a közfelügyeleti hatóság jár el másodfokú hatóságként (Bardócz, 2016).

A szabályozói környezet változása miatt érdemes megnézni, hogyan alakult az elmúlt években a könyvvizsgálatra kötelezett vállalkozások száma, illetve a kamarai tagok létszáma. A 2017. év végén a kamarai tagok létszáma összesen 4567 fô volt, amelyból a könyvvizsgálói tevékenység ellátását nem szüneteltető tagsági jogállású kamarai, vagyis aktív tagok száma 2548 fô, a könyvvizsgálói tevékenység ellátását szüneteltetô tagsági jogállású kamarai tagoké, vagyis a szüneteltetô tagoké 2019 fố volt. Az összes kamarai tag könyvvizsgálók száma az elôző évhez viszonyítva 209 fôvel csökkent, ebből az aktív tagoké 124 fơvel, a szüneteltetôké 85 fôvvel változott. 2017-ben 23 tagfelvételi kérelemrôl határozott a kamara felvételi bizottsága. 10 fớt a könyvvizsgálói tevékenység ellátását szüneteltetố tagsági jogállású kamarai tagként, 13 fốt a könyvvizsgálói tevékenység ellátását nem szüneteltető tagsági jogállású kamarai tagként, aktív tagként vett nyilvántartásába. A vizsgált évben összesen 21 fố tett esküt a kamara elnöke elôtt. A bizottság kérelemre 205 fó, hivatalból 15 fơ kamarai tagot törölt a nyilvántartásból, illetve 12 fó elhunyt 2017-ben. ${ }^{3}$

1. táblázat: Könyvvizsgálók és könyvvizsgált beszámolók (2010-2016)

\begin{tabular}{l|c|c|c|c|c|c|c}
\hline Megnevezés & $\mathbf{2 0 1 0}$ & $\mathbf{2 0 1 1}$ & $\mathbf{2 0 1 2}$ & $\mathbf{2 0 1 3}$ & $\mathbf{2 0 1 4}$ & $\mathbf{2 0 1 5}$ & $\mathbf{2 0 1 6}$ \\
\hline $\begin{array}{l}\text { Aktív tagok száma } \\
\text { (fó) }\end{array}$ & 3376 & 3296 & 3141 & 3030 & 2931 & 2831 & 2672 \\
\hline $\begin{array}{l}\text { Szüneteltetó tagok } \\
\text { száma (fó) }\end{array}$ & 2317 & 2318 & 2313 & 2317 & 2270 & 2199 & 2104 \\
\hline $\begin{array}{l}\text { Összes tag (fó) } \\
\text { Könyvvizsgált beszá- } \\
\text { molók száma (db) }\end{array}$ & 45096 & 42921 & 35547 & 32947 & 28564 & 27873 & 24345 \\
\hline
\end{tabular}

Forrás: Saját szerkesztés a www.mkvk.hu adatai alapján

A jogszabályi változások miatt a könyvvizsgálóknak számos piaci kihívással kell szembenézniük. A globalizáció kiterjedésével szúkült a hagyományos auditpiac, illetve kapcsolatitôke-bázisúvá vált. Az auditdíjtételek stagnálnak vagy inflációkövetôvé váltak. Nemzetközi szinten, illetve fejlett piagazdaságok országaiban a hagyományos kockázatfeltáráson alapuló könyvvizsgálat mellett az auditorok egyéb tevékenységeket is végeznek, mint a tanácsadás, üzleti kockázatok beazonosítása és csökkentése. Jelenleg a könyvvizsgálók az éves beszámolókat ellenôrzik, amely ellenôrzés egy utólagos ellenőrzést jelent, évente ismétlődve. A jövőbeni előremutatások alapján az audit egy folyamatos és valós idejú ellenőrzés lehetne, amely magában foglalja az információs rendszerek és folyamatok átvilágítását is. 
Lukács László István - Török Martina Zsófia: A magyar könyvvizsgálat történetének...

\section{KÖVETKEZTETÉSEK}

Tanulmányunkból látható, hogy Magyarországon már a középkor végén is fontos szerep jutott az uralkodói bevételekrôl készített nyilvántartások pénzügyi ellenőrzésének, amely késóbb kiterjedt a kereskedelmi tevékenységre is. A számvitel és ellenôrzés fejlódése a Habsburg-uralkodóknak köszönhetôen jól követte a fejlettebb nyugat-európai országokét. A magyar számvitel és könyvvizsgálat a 19. század végén és a 20. század elsô felében dinamikus fejlődést mutatott, ami nagyrészt az erôteljes osztrák, késôbbiekben a német befolyásnak köszönhető, másrészt a Magyar Könyvviteli Folyóirat szerkesztőségének és a szakma iránti elkötelezettségüknek. Habár a második világháborút követôen a könyvvizsgálók képzése nem szúnt meg, maga a szakma a rendszerváltásig „feledésbe merült”, mélypontra került, mert a könyvvizsgálók csak a tervgazdaság igényeit elégítették ki vállalati ellenőri tevékenységükkel. A magyar könyvvizsgálat a rendszerváltást követôen éledt újra, tulajdonképpen negyvenévnyi hátrányból indult a nyugati országokhoz képest, de hazánk hamar behozta a lemaradását, csatlakozott a nemzetközi szakmai szervezetekhez, és adaptálta normáikat, alkalmazza a módszereiket.

\section{JEGYZETEK}

1 Magyar Könyvvizsgáló Kamara (MKVK), www.mkvk.hu.

2 Az elôadás jegyzetének kiadása évszám nélküli, de a hozott mintapéldák és a legfrissebben hivatkozott jogszabályok alapján az 1939-es évre tehetô a kiadása.

3 www.mkvk.hu, FEB-beszámoló.

\section{FELHASZNÁLT IRODALOM}

Bardócz Iván (2016): Reform a könyvvizsgálat szabályozásában I. Wolters Kluver, Budapest.

Borbás Máté (2007): A könyvvizsgálat története Magyarországon. Magyar Könyvvizsgálói Kamara, Budapest.

Erdély Sándor (1930): Mérleg és adómérleg készítésének irányelvei és bírálata. Grill Károly Könyvkiadóvállalata, Budapest.

Kardos Barbara (2011): A számvitel története. Szám-adó, 20. évf., 3. sz., 3-9.

Kenyeres István (2012a): A Magyar Királyság jövedelmei és kiadásai Hunyadi Mátyás és a Jagellók korában. Rubicon, 23. évf., 6. sz., 42-45.

Kenyeres István (2012b): Pecunia nervus belli. A háború alapja a pénz. A Magyar Királyság, illetve a Habsburg Monarchia bevételei és kiadásai, valamint a hadiköltségek Mohácstól a tizenöt éves háború végéig. Rubicon, 23. évf., 6. sz., 46-49.

Kresalek Péter (2014): A vállalati ellenốrzés alapjai. Oktatási segédanyag, Budapest.

Kuntner Róbert - Szél Jenô (szerk.) (1932): Magyar Könyvviteli Folyóirat, 23. évf., 5-6. sz., Hites könyvvizsgálói szám. Athenaeum Irodalmi és Nyomdai Rt., Budapest.

Kuntner Róbert (1939): Mérlegelemzés és revizió. Magyar Élet Könyvesbolt, Budapest.

Lukács János (2014): A könyvvizsgálat alapjai. Budapesti Corvinus Egyetem, Budapest.

Lukács László István (2012): A számvitel évszázadai. Mozaikok a számbavétel történelmébôl és fejlódésébôl. OTDK-dolgozat, Budapesti Gazdasági Főiskola, Budapest.

Printz János (2013): Tájékoztató az államháztartás szervezetei könyvvizsgálatának helyzetérôl. Könyvvizsgálók Lapja, 2. évf., 3. sz., 5-6.

Rajty Tivadar (1941): A hites könyvvizsgálat jogszabályai és a hites könyvvizsgálói intézmény Magyarországon. Magyar Hites Könyvvizsgálók Egyesülete, Budapest. 
Sainty, John Christopher (1983): Officers of the Exchequer. List and Index Society, Special Series 18, $135-139$.

Securs, Claus C. (2014): A könyvvizsgáló szakma helyzete Németországban. Számvitel, Adó, Könyvvizsgálat, 56. évf., 10. sz., 468-470.

Steiner Vilmos (1941): Az üzemszervezés és a könyvvizsgálat az új magyar gazdasági életben. Madách-nyomda, Budapest.

Sztanó Imre (2015): A számvitel alapjai. Perfekt, Budapest.

Vál Ottó - Jaszenovics Géza (1926): Vezérfonál az adóügyi hatóságok és bíróságok által elrendelt könyvvizsgálat és üzletvitel-birálat eszközléséhez. Jaszenovics, Fábián és Társa, Budapest.

Zaid, Omar Abdullah (2004): Accounting Systems And Recording Procedures in the Early Islamic State. Accounting Historians Journal, Vol. 31, No. 2, https://doi.org/10.2308/0148-4184.31.2.149.

Zwierina Jenô (1949): Mérlegtan és mérlegbirálat. Pantheon Irodalmi Intézet, Budapest.

\section{JOGSZABÁLYOK}

1723. évi LIII. törvénycikk: A könyvkivonati per rendjérôl s miként kelljen az eddigelé keletkezett adósságok iránt a kereskedôknek eljárni? (Kereskedelmi dekrétum.) Internetes forrás. Online: https://net.jogtar. hu/ezer-ev-torvenyei?pagenum=27 Elérve: 2019. március 10.

1840. évi XVI. törvénycikk a kereskedôkrôl (Kereskedôi törvénycikk). Internetes forrás. Online: https:// net.jogtar.hu/ezer-ev-torvenyei?pagenum=27 Elérve: 2019. március 10.

1875. évi XXXVII. törvénycikk, kereskedelmi törvény (Kt.). Internetes forrás. Online: http://jogiportal. hu/index.php?id=a5d45cba58c925e8f\&state=19960810\&menu=view Elérve: 2019. március 10.

1930. évi V. törvénycikk a korlátolt felelôsségú társaságról és a csendes társaságokról (Kft. törvény). Internetes forrás. Online: https:/ / net.jogtar.hu/ezer-ev-torvenyei?pagenum=27 Elérve: 2019. március 10.

2000. évi C. törvény a számvitelrôl

2007. évi LXXV. törvény a Magyar Könyvvizsgálói Kamaráról, a könyvvizsgálói tevékenységrôl, valamint a könyvvizsgálói közfelügyeletrôl

2017. évi CL. törvény az adózás rendjérôl

2014/56/EU irányelv az éves és összevont (konszolidált) éves beszámolók jog szerinti könyvvizsgálatáról szóló 2006/43/EK irányelv módosításáról

Magyar Nemzeti Könyvvizsgálati Standardok 